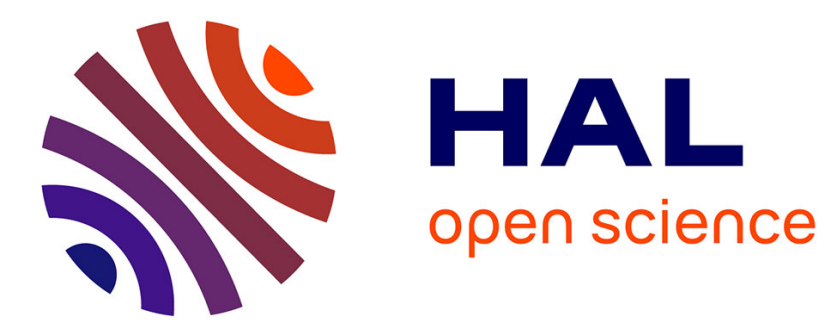

\title{
Origin and characteristics of the zooplankton phosphatase activity in a coastal ecosystem of the Mediterranean Sea (Toulon bay)
}

Magali Lespilette, Gérard Bogé, Simone Richard, Jean-Louis Jamet

\section{To cite this version:}

Magali Lespilette, Gérard Bogé, Simone Richard, Jean-Louis Jamet. Origin and characteristics of the zooplankton phosphatase activity in a coastal ecosystem of the Mediterranean Sea (Toulon bay). Marine Environmental Research, 2007, 63 (5), pp.445. 10.1016/j.marenvres.2006.12.004 . hal-00501897

\section{HAL Id: hal-00501897 \\ https://hal.science/hal-00501897}

Submitted on 13 Jul 2010

HAL is a multi-disciplinary open access archive for the deposit and dissemination of scientific research documents, whether they are published or not. The documents may come from teaching and research institutions in France or abroad, or from public or private research centers.
L'archive ouverte pluridisciplinaire $\mathbf{H A L}$, est destinée au dépôt et à la diffusion de documents scientifiques de niveau recherche, publiés ou non, émanant des établissements d'enseignement et de recherche français ou étrangers, des laboratoires publics ou privés. 


\section{Accepted Manuscript}

Origin and characteristics of the zooplankton phosphatase activity in a coastal ecosystem of the Mediterranean Sea (Toulon bay)

Magali Lespilette, Gérard Bogé, Simone Richard, Jean Louis Jamet

PII:

S0141-1136(06)00218-2

DOI:

10.1016/j.marenvres.2006.12.004

Reference:

MERE 3081

To appear in:

Marine Environmental Research

Received Date: $\quad 17$ March 2006

Revised Date: $\quad 4$ December 2006

Accepted Date: $\quad 6$ December 2006

Please cite this article as: Lespilette, M., Bogé, G., Richard, S., Jamet, J.L., Origin and characteristics of the zooplankton phosphatase activity in a coastal ecosystem of the Mediterranean Sea (Toulon bay), Marine Environmental Research (2006), doi: 10.1016/j.marenvres.2006.12.004

This is a PDF file of an unedited manuscript that has been accepted for publication. As a service to our customers we are providing this early version of the manuscript. The manuscript will undergo copyediting, typesetting, and review of the resulting proof before it is published in its final form. Please note that during the production process errors may be discovered which could affect the content, and all legal disclaimers that apply to the journal pertain. 
1 Origin and characteristics of the zooplankton phosphatase activity

2 in a coastal ecosystem of the Mediterranean Sea (Toulon bay)

4 Magali Lespilette, Gérard Bogé *, Simone Richard and Jean Louis Jamet

6 PROTEE-EBMA EA. 3819

7 Département de Génie Biologique

8 Université du Sud Toulon -Var (USTV)

9 BP20132

10 F-83957 La Garde Cedex

$\underline{\text { Abstract: }}$

In Toulon Bay (France), very high phosphatase activities have been found in the zooplankton fraction $>90 \mu \mathrm{m}$. This work was intended to specify their origin. For that purpose, larvae, juvenile and adult Crustacea (Copepods: Calanoids, Cyclopoids, Branchiopods: Cladocera, and Cirripeds) were isolated. Their activities were measured using paranitrophenyl phosphate dissolved in sea water in order to calculate $\mathrm{Km}$ (the enzyme half saturation concentration) and Vmax (the reaction rate when the enzyme is saturated with substrate). Vmax were referred to protein contents of the isolated organisms to calculate specific activities. For all zooplankton groups high and low affinity phosphatase activities were found. The low affinity enzyme was responsible for at least $70 \%$ of the total phosphatase activity. Its specific activity was higher for larvae than for copepodites and adults. In Cirriped nauplii this activity was particularly high with values which were several hundred times higher than that in other Crustacea. These enzymes had optimum $\mathrm{pH}$ close to 8.4, magnesium requirement and were competitively inhibited by orthophosphate. Experiments with intact and lysed Cirriped nauplii confirmed that living organisms had only a weak external activity and showed that most of the activity of these larvae was primarily intracellular.

$30 *$ Corresponding author.

31 E-mail address : boge@univ-tln.fr (G. Bogé) 


\section{Introduction:}

36 Much of the hydrolysis of phosphate esters in the aquatic environment results from the presence

37 of enzymes on the cell surface or in the periplasmic space of bacteria and phytoplankton

38 (Ammerman, 1991, Ammerman and Glover, 2000). However, enzymatic activities are also

39 secreted by bacteria and phytoplankton, or released into the medium following the death of

40 planktonic organisms (Jansson et al, 1988; Hoppe, 2003; Nausch and Nausch, 2004). In

41 phytoplankton, as in bacteria, phosphatases, particularly alkaline phosphatase, can be induced

42 under conditions of phosphorus limitation; nevertheless, some forms of phosphatase activity are

43 constitutive and their synthesis is independent of external phosphorylated compounds (Cembella

44 et al., 1984).

45 Zooplankton are generally not regarded as an important contributor to phosphate ester hydrolysis.

46 However, as early as 1951, Margalef speculated that soluble phosphatases could be produced by

47 zooplankton (Boavida, 2005). Phosphatase secretion from zooplankton has been characterised

48 notably in Daphnia, Bosmina, Holopedium, and Cyclops (Jansson et al.,1988) and may contribute

49 to the overall phosphatase activity in fresh water. In sea water, we observed very high specific

50 activities in homogenates of the $>90 \mu \mathrm{m}$ size class of the particulate material in Toulon Bay when

51 the abundances of cirriped larvae were high (Gambin et al., 1999, Bogé et al., 2002; Jean et al.,

52 2003; Bogé et al., 2006). This work was undertaken to give deeper insight into the origin of the

53 zooplankton phosphatase activities originated from Toulon Bay. Phosphatases activities were

54 investigated by measuring the biochemical constants, $\mathrm{Km}$ and Vmax. We first identified the

55 taxonomic groups responsible for such activities. For that purpose, developmental stages of

56 zooplankton groups (Copepodes : Calanoids, Cyclopoids, Branchiopodes : Cladocera, and

57 Cirripeds) were isolated separately. So the influence of phytoplankton and detritus was excluded.

58 A particular study was then carried out with Cirriped larvae to specify the localization of

59 phosphatases. By using living larvae, it was possible to measure the internal, external and

60 secreted activities. A study of its cation requirement, of its $\mathrm{pH}$ dependence and of the phosphorus

61 inhibition has been also carried out. 


\section{Material and Methods :}

64 Origin and isolation of zooplankton: Zooplankton were collected using a $90 \mu \mathrm{m}$ net in May 2003 and June 2005, from Toulon Bay on the French Mediterranean Coast. Zooplankton were immediately brought to the laboratory, and were frozen at $-20^{\circ} \mathrm{C}$ in natural seawater to immobilize the organisms and to facilitate their isolation. Zooplankton were then thawed at ambient temperature. We used a binocular lens and a dissecting needle with a wire loop ending to isolate and collect larval, juvenile and adult specimens of Copepoda (Calanoids and Cyclopoids), Branchiopods (Cladocera), Cirripeds and Malacostracea. About thirty individuals of each group were placed in Eppendorf tubes containing $250 \mu$ d distilled water. We observed that when the congelation lasted between 2 and 20 hours, most zooplankton were immobile, except for some Cirriped larvae that were still alive. Enzyme activities were measured on dead organisms isolated from zooplankton frozen during at least 24 hours, except for the last experiment for which living Cirriped larvae were needed. In that case, the larvae were patiently isolated without previous congelation.

Phosphatase activity: Batches of zooplankton were lysed by sonication at $2^{\circ} \mathrm{C}$ and the homogenates were used as enzyme sources. The substrate was paranitrophenyl phosphate (pNPP), dissolved in sea water which had been prefiltered through $0.45 \mu \mathrm{m}$ pore-size filters. Paranitrophenol (PNP) produced during the reaction was detected at $410 \mathrm{~nm}$ during one hour

82 (Reichardt et al., 1967). The experiments were carried out at $25^{\circ} \mathrm{C}$. The biochemical constants

$83 \mathrm{Km}$ (the half saturation concentration) and Vmax (the reaction rate when the enzyme is saturated

84 with substrate) were calculated by means of an iteration program based on an analysis of Eadie

85 Hofstee kinetics. Previous work showed that these kinetics are composed of two Michaelian 86 components: a low affinity/high capacity mechanism and a high affinity/low capacity mechanism

87 (Jean et al., 2003, Bogé et al., 2002, 2006). For each extract at least four substrate concentrations

88 (0.01 to $10 \mathrm{mM}$, in geometrical progression) were tested and the Vmax of each component was 89 calculated.

90 Phosphatase activity is typically $\mathrm{pH}$ dependent (Hope, 2003). The $\mathrm{pH}$ dependence of Cirriped

91 phosphatase activity was studied for a $15 \mathrm{mM}$ substrate concentration prepared in prefiltered sea 92 water. Glycine $(50 \mathrm{mM})$ was used to buffer this medium at alkaline $\mathrm{pH}$ values(7.22 to 10.24). 
93 Phosphatase activity is also influenced by specific cations (Mc Comb et al.,1979). The cation

94 dependence of the Cirriped activity has been studied. Experiments were carried out with synthetic 95 water made of distilled water adjusted to $\mathrm{pH} 8.4$ with glycine (final concentration: $50 \mathrm{mM}$ ), and 96

97 chloride salts) and pNPP (15 mM).

98 Orthophosphate competitively inhibits phosphatase activity at high phosphorus concentrations

99 (Chrost, 1991). To investigate the influence of phosphorus on the zooplankton phosphatase 100 activity, Cirriped larvae homogenates were used. The effect of $5 \mathrm{mM} \mathrm{K}_{2} \mathrm{HPO}_{4}$ on the hydrolysis 101 of pNPP (0.083 mM to $6.7 \mathrm{mM}$ ) was studied. At this concentration, phosphorus precipitates in 102 sea water. To avoid this precipitation and to demonstrate the relevance of phosphate inhibition for 103 seawater, natural seawater was replaced by synthetic sea water, containing $500 \mathrm{mM} \mathrm{NaCl}, 50$ $104 \mathrm{mM} \mathrm{MgCl}$, and $20 \mathrm{mM} \mathrm{KCl}$, buffered at $\mathrm{pH} 8.4$ with glycine.

105 An experiment was devoted to the study of the localization of the phosphatase activity in Cirriped 106 larvae. Phosphatases are either internal or external enzymes (Jansson et al., 1988). The hydrolysis 107 of substrates in the water is due to external enzyme activities whereas that of intracellular 108 compounds results from internal enzymes. To characterize external enzyme activity, living 109 Cirriped nauplii were placed in sea water with $15 \mathrm{mM}$ pNPP. The PNP concentrations were then 110 followed over one hour. The same experiment was carried out using larvae homogenates to 111 characterise total phosphatase activities, including internal and external enzymes. We also looked 112 for secreted phosphatase activity in water conditioned by larvae for 24 hours.

114 Proteins: To evaluate specific phosphatase activities, protein concentrations of the plankton 115 extracts were determined according to Lowry's method (1951). Specific activity was defined as 116 the ratio between enzyme activity and protein concentration.

118 Statistics: At least three batches of zooplankton were used for each taxonomic group (10 119 experiments for Calanoids, 3 experiments for cirriped larvae, and 5 for the other taxonomic 120 groups). Standard errors are presented. Non parametric tests were used for Vmax intergroup comparisons (Mann Whitney). 


\section{Results:}

125 Structure of the zooplankton community in Toulon Bay:

126 In June 2005, the zooplankton community averaged 19000 individuals per $\mathrm{m}^{3}$. Nearly $89 \%$ of

127 the zooplankton were crustaceans (Fig. 1). Copepoda was the largest group. Cyclopoids, 128 particularly Oithona nana, were the most numerous Copepoda. Several developmental stages 129 were found: only $34 \%$ of the zooplankton community and 39\% of the Copepoda group was 130 adult; $43 \%$ of total zooplankton and $48 \%$ of Copepoda were copepodites, $23 \%$ of total 131 zooplankton and $13 \%$ of Copepoda were larvae. The Cirriped larvae were almost all nauplii and 132 made up only $1 \%$ of the zooplankton community. Eleven $\%$ of the community were larvae that 133 were not Crustacea. Less than $1 \%$ of total zooplankton were Decapodes zoe.

135 Interspecies comparisons: Phosphatase activities with high and low affinities were found for all 136 zooplankton groups. The Km for the low affinity activity was between 0.3 and $1 \mathrm{mM}$. For the 137 high affinity activity, it was below $0.02 \mathrm{mM}$. At least $70 \%$ of the phosphatase activity (expressed 138 as Vmax) was supported by low affinity enzymes (Fig. 2). The contribution of this low affinity 139 component to the to overall phosphatase activity (expressed as Vmax) was more important in 140 Zoe (Decapods: ZDec) and nauplii (Cyclopoids: Ncycl and Cirripeds: NCir), than in adults 141 (Cyclopoids: ACycl and Calanoids: ACal) and copepodites (Calanoids: CCala). For Cirriped 142 nauplii (NCir), more than $99 \%$ of the phosphatase activity was due to low affinity enzyme. 143 Conversely, the contribution of high affinity activity was predominant in Copepod adults 144 (Cyclopoids: ACycl, and Calanoids: ACal) and copepodites (Calanoids: CCala). The relative 145 proportion of the phosphatase activity due to the high affinity enzymes was substantially lower in 146 Branchiopods (Cladocera) than in Copepods.

148 The Vmax of the low affinity enzyme showed considerable differences between developmental 149 stages (Fig. 3). In Copepods (Cyclopoids and Calanoids), Vmax values were relatively low for 150 adults and copepodites (ACycl, ACal and CCala), but were approximately 50 times higher for 151 nauplii ( $\mathrm{NCycl}$ ) than for adults. However, there was substantial variability between batches for 152 this group. Significantly higher activities existed in Branchiopod (Cladocera) adults than in 153 Copepoda $(\mathrm{p}<0.05)$. But the most exceptional activities were found for Cirriped nauplii. Their 
154 specific phosphatase activity was approximately 70 times higher than for Copepoda nauplii and more than 1000 times higher than for adult Copepoda. The differences with the other taxonomic groups were highly significant $(\mathrm{p}<0.05)$.

The Vmax of the high affinity enzyme was always lower than the Vmax of the low affinity component (Fig. 4). Copepod larvae and copepodites (Calanoid copepodites: CCal and Cyclopoid nauplii: NCycl) in addition to Cirriped nauplii (Cirriped nauplii: NCir) had the highest activities (not statistically significant except for Cirriped nauplii with $\mathrm{p}<0.05$ ). However, for Cirriped, the high values of the low affinity activity made the accurate determination of the high affinity activity more difficult.

Analysis of the phosphatase activity of Cirriped nauplii: We characterised the phosphatase activity of Cirriped nauplii, including its dependence on $\mathrm{pH}$, cations and phosphorus, and its cellular localisation..

- pH dependence: pNPP hydrolysis by the larvae had a pH optimum of 8.4, close to that of sea water (Fig. 5). At pH 7 this activity was still significant since it accounted for approximately $40 \%$ of its maximum value. This is also the case at $\mathrm{pH} 9.5$ where this percentage was $27 \%$, whereas, the activity was completely inhibited at $\mathrm{pH} 10$.

- Role of cations: Phosphatase activity was inhibited by almost $90 \%$ when the substrate was prepared in fresh water instead of in seawater. In synthetic water made of $50 \mathrm{mM} \mathrm{Mg}{ }^{2+}, 20$ $\mathrm{mM} \mathrm{Ca}{ }^{2+}, 500 \mathrm{mM} \mathrm{Na}{ }^{+}$and $50 \mathrm{mM} \mathrm{K}$, phosphatase activity was nearly $70 \%$ of its seawater value. Individually, these ions stimulated the activity unequally. With magnesium (up to $50 \mathrm{mM}$ ) the activity reached nearly $40 \%$ of its level in sea water. Sodium also stimulated the activity, but to a lesser extent. For $500 \mathrm{mM}$ Na the activity was only $20 \%$ of its level in sea water. The other ions like calcium and potassium had more limited effects (Fig. 6).

- Role of phosphorus: In the synthetic medium, the Vmax of Cirriped larvae phosphatase activity was approximately $25 \%$ lower than in sea water without any significant change in its $\mathrm{Km}$. The Km was typically $0.3 \mathrm{mM}$ in the absence of phosphate and $0.6 \mathrm{mM}$ in its presence; the 
185 Vmax remained unchanged (Fig. 7). This Km effect indicates that phosphorus competitively 186 inhibited the Cirriped larvae activity.

187

188 -Localization of phosphatase activity: Very high phosphatase activities were found when 189 larvae homogenates were used (Fig. 8), whereas intact larvae gave very low pNP concentrations. 190 Very low phosphatase activities were found in the water where larvae remained for 24 hours. 191 These results indicate that phosphatase activity associated with Cirriped larvae was essentially 192 intracellular. 


\section{Discussion:}

196 We investigated the role of marine zooplankton in the production of enzymes involved in the metabolism of phosphorylated compounds in Toulon Bay on the French Mediterranean Coast. These compounds are of major importance for plankton growth and for the control of cellular activities.

We confirmed that in size fractionation experiments (Jean et al. 2003, Bogé et al. 2006, Gambin et al. 1999, Jamet and Bogé, 1998) the hydrolysis of phosphate esters by zooplankton could be described by two Michaelian mechanisms with distinct $\mathrm{Km}$ and Vmax. This work specifies that, on the basis of their Vmax, the contribution of the low affinity activity was always more significant than that of the high affinity activity, particularly in larvae. The high affinity activities have been revealed with adults as well as larvae. They could be active in the local hydrolysis of low phosphoric ester concentrations, as found in the natural medium. Previous results have suggested that bacteria may contribute to the phosphatase activity associated with the $>90 \mu \mathrm{m}$ size class fraction, which is mostly composed of zooplankton. But they cannot explain the high levels of the low affinity activity (Gambin et al., 1999; Jean et al., 2002).

The low affinity activity is probably responsible for the hydrolysis of intracellular substrates.

211 Indeed, this activity cannot be detected extracellularly with intact Cirriped nauplii as the enzyme

212 source (Figure 8). We also showed that this low affinity activity fluctuated greatly according to 213 the developmental stages of the zooplankton. In adults and juveniles (copepodites), phosphatase

214 levels were generally low, notably in Cyclopoids, Cladocera and Calanoids. Phosphatase activity 215 in larvae was more variable, but was generally higher as observed for Copepoda nauplii (Figure 216 3). In Toulon Bay, nauplii were only approximately $13 \%$ of the total number of Copepods during 217 the sampling period (Figure 1).

218 Since the phosphatases are internal activities it is thus possible that zooplankton lose a major part 219 of their enzyme activity after the freezing treatment. To test this possibility additional 220 experiments have been carried out. Copepods were isolated from fresh and pre-frozen 221 zooplankton. The results indicated that the activities of individuals isolated from pre-frozen zooplankton were lower, but the differences with fresh zooplankton were not significant due to natural intra-species variation. Cirriped nauplii are much more tolerant to freezing, and their cell membranes are probably better at withstanding freezing or thawing. The possible under estimate 
225 of the activity of pre-frozen copepod does not change the conclusion that the activity of the 226 cirriped larvae was considerably higher.

227 The role of these high phosphatase activities remains obscure. Physiologically, phosphatases 228 could contribute to the synthesis or to the use of nutritional or energy reserves. In nauplii the 229 mean $\mathrm{P}$ content is higher than in adults which could be related with higher phosphatase activities 230 (Carillo et al., 2001). Nauplii have several stages during which molting and growth take place.

231 Naupliar stage I derives energy from remaining egg yolk reserves, while stages II through VI 232 derive their energy from consumed phytoplankton. In egg yolk, glycolipoproteins are an 233 important source of proteins, lipids, and carbohydrates (De Chaffoy de Courelles and Kondo, 234 1980). Phosphate has been found covalently bound on these proteins in insects and crustaceans 235 (Allerton and Perlmann, 1965; Fialho et al., 2002; De Chaffoy de Courelles and Kondo; 1980). In 236 Crustacea, the degradation of these reserves is greatest during the nauplii stage due to enhanced 237 lysosomal hydrolytic activities (Perona and Vallejo; 1985). In Artemia, these activities include 238 cathepsin B acid ribonuclease, acid deoxyribonuclease, acid phosphatase, acid phosphodiesterase, $239 \beta$-glucosidase, $\beta$ - $N$-acetylgalactosaminidase and acid lipase (Perona and Vallejo, 1985). Nucleic 240 acids, mono and poly-phosphate esters are also possible sources of organic phosphorus for 241 plankton (Benitez-Nelson, 2000). Phosphatases (acid and alkaline), and nucleotidases catalyze 242 the hydrolysis of these compounds (Hope, 2003). These activities catalyze also pNPP hydrolysis.

243 The most striking observation of this work was the high specific phosphatase activity associated 244 with Cirriped larvae, several hundred times higher than for other taxons. In Toulon Bay, Cirriped 245 nauplii accounted for less than $1 \%$ of the total zooplankton community. Higher abundances were 246 generally found in May, June and August, but they never exceed 400 individuals per $\mathrm{m}^{3}$ (Jean et 247 al. 2003). During these periods the phosphatase activity of zooplankton homogenates peaks such 248 that the contribution of zooplankton to the total particulate activity reached $80 \%$ or more 249 (Gambin et al., 1999). On the other hand when these larvae are absent, the activity of the 250 zooplankton falls by more than $90 \%$ (Jean et al.2003).

251 The fertilized eggs of Cirripeds are brooded within the shell of adults. When they change into 252 nauplius larvae, they are released into the water as free-swimming plankton. After several moult 253 stages, they become cyprid larvae. These larvae are enclosed within a carapace and possess 254 antennae and numerous appendages. They also have detectors that can recognise suitable solid 255 substrata. During settlement, glands of the antennae secrete a special cement to attach the larvae 
256 to a rock (Anderson, 1994; Foster, 1987). During these larvae nauplii stages, reserves, consisting 257 of lipids and proteins, are also synthesized in abundance. These reserves are necessary for later 258 stages, particularly for the cyprid stage which does not feed during settlement. In Balanus 259 amphytrite, the concentration of a specific protein, the cyprid major protein (CMP), accumulates 260 in the haemocoel, increases during the naupliar stages and decreases with aging of cyprids and 261 during the early juvenile period (Satuito et al.,1996; Shimizu et al., 1996). This protein appears to 262 function as a storage protein during settlement of cyprids as well as during metamorphosis to 263 juveniles. It shares similarities with the egg-yolk phosphoprotein, vitellin. Incidentally, this protein may explain the unusual freeze resistance of these larvae, which can survive several hours at $-20{ }^{\circ} \mathrm{C}$ (personal observation). The high phosphatase activities found in Cirriped larvae of Toulon Bay could thus play an important role in the dephosphorylation of this protein or of other 267 phosphorylated compounds during the fasting period.

268 These internal activities can also influence the regeneration of phosphate. It is generally accepted that less than $20 \%$ of ingested phosphorus is used for growth. The remainder is excreted in the medium as soluble reactive phosphorus and organic phosphorus (Valiela, 1995). In Swedish west coast, Bamstedt (1985) showed, that excretion rates of inorganic phosphate and dissolved organic

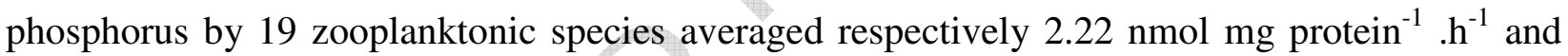
$0.8 \mathrm{nmol} \mathrm{mg}$ protein ${ }^{-1} \cdot \mathrm{h}^{-1}$ in spring. Taking into account the protein contents of barnacle nauplii,

274 the quantities rejected per individual nauplius would approximate respectively $0.01 \mathrm{nmol}^{-1}$ and $0.0036 \mathrm{nmol} \cdot \mathrm{h}^{-1}$. But due to the very high specific phosphatase activities, the excretion of inorganic phosphate is probably higher, except in cypris which do not feed. These intracellular activities could also contribute to the hydrolysis of phosphorylated compounds of sea water when enzymes are released in sea water from dead cells (Jansson et al., 1988). In the case of Cirriped nauplii, the activity was approximately $200 \mathrm{nmol} \cdot \mathrm{l}^{-1} \cdot \mathrm{h}^{-1}$ in May-June and the dissolved activity was $450 \mathrm{nmol} . \mathrm{l}^{-1} . \mathrm{h}^{-1}$ during the same period (Bogé et al., 2006). So it is thus possible that part of this dissolved activity comes from dead larvae.

282 Some characteristics of this activity have been also specified in this work. This activity had a $\mathrm{pH}$ 283 optimum close to 8.4. It was strongly stimulated by the sea water components (Figure 6) and it was inhibited by high orthophosphate concentrations (Figure 7). These results are in agreement with previous data obtained on homogenates from particulate material of the $>90 \mu \mathrm{m}$ size class

286 (Gambin et al. 1999). This work brings additional information concerning the role of sea water 
cations. Magnesium was most effective, which suggests that the enzyme could be alkaline

288 phosphatase, its activity being generally controlled by this cation (McComb et al.. 1979, Jansson

289 and Al, 1988). Sodium also stimulated the phosphatase activity of the larvae (Figure 6) but high

290 concentrations were required (up to $500 \mathrm{mM}$ ). So it is possible that this effect comes from the

291 high tonicity that these high concentrations generate (McComb and al.1979).

292 In conclusion, this work showed that zooplankton of Toulon bay has phosphatase activities with

293 low and high affinities; that these activities are higher in larvae and in particular in Cirriped

294 larvae where they could be of great importance for their metabolism and for the regeneration of 295 phosphate.

\section{Acknowledgments}

This work was supported by Region Provence-Alpes-Côte-d'Azur and Communauté

300 d'Agglomérations Toulon-Provence-Mediterranée. The authors are grateful to Laetita De Souza

301 and Typhaine Vettard for their efficient technical assistance. 


\section{$\underline{\text { References }}$}

Allerton, S.E. \& Perlmann, G.E. (1965). Chemical characterization of the phosphoprotein phosvitin. J. Biol. Chem. 240, 3892-3898.

Ammerman, J.W. (1991). Role of ecto-phosphohydrolases in phosphorus regeneration in estuarine and coastal ecosystems. In Chrost, R.J. (ed), Microbial Enzymes in Aquatic Environments. Springer Verlag, Berlin, pp.165-186.

Ammerman, J.W. \& Glover, W.B. (2000). Continuous underway measurement of microbial ectoenzyme activities in aquatic ecosystems. Mar Ecol Prog Ser, 201, 1-12

Anderson, D.T. (1994). Barnacles: structure, function, development and evolution. Chapman and Hall (ed), London, 346 pp.

Bamstedt, U.(1985). Seasonal excretion rates of macrozooplankton from the Swedish west coast. Limnol. Oceanogr. 30(3), 607-617.

Benitez-Nelson, C.(2000). The biogeochemical cycling of phosphorus in marine systems. EarthScience Reviews, 51, 109-135.

Boavida, M. (2005). ASLO Summer Meeting, Santiago da Compostela, Spain.

Bogé, G., Jamet, J.L., Richard, S., Jamet, D., \& Jean, N. (2002). Contribution of copepods, cladocerans and cirripeds to phosphatase activity in Mediterranean zooplankton.

Bogé, G., Jean, N., Jamet, J.L., Jamet, D., \& Richard, S. (2006). Seasonal changes in Hydrobiologia, 468, 147-154. 18. 
333 Carillo, P., Villar-Argaiz M., Medina-Sanchez, J.M. (2001). Relationship between N:P ratio and growth rate during the life cycle of calanoid copepods. An in situ measurement. Journal of Plankton Research, 23, 5, 537-547.

Cembella, A.D., Antia, N.J, \& Harrison, P.J. (1984). The utilization of inorganic and organic phosphorus compounds as nutrients by eukaryotic microalgae: a multidisciplinary perspective: Part 2. CRC Crit. Rev. Microbiol. , 10, 317-391.

Chrost, R.J. (1991). Environmental control of the synthesis and activity of aquatic microbial ectoenzymes. In Chrost R.J. (ed) Microbial enzymes in aquatic environments. Springer Verlag, Berlin, pp.29-59.

De Chaffoy de Courcelles, D. \& Kondo, M. (1980). Lipovitellin from the crustacean, artemia salina. Biochemical analysis of lipovitellin complex from the yolk granules. J. Biol. Chem., $255,14,6727-6733$.

Fialho, E., Silveira, A B., Masuda, H. \& Silva-Neto, M A.C. (2002). Oocyte fertilization triggers acid phosphatase activity during Rhodnius prolixus embryogenesis. Insect Biochemistry and Molecular Biology, 32, 871-880.

Foster, B.A. (1987). Barnacle ecology and adaptation. In: Southward, A.J. (ed) Crustacean Issues 5 : Barnacle Biology. Balkema, A.A., Rotterdam,pp. 113-133

Gambin, F., Bogé, G., \& Jamet, D. (1999). Alkaline phosphatase in a littoral Mediterranean marine ecosystem: role of the main plankton size classes. Marine Environmental Research, 47,441-456.

Jamet D.\& Bogé G. (1998). Characterisation of marine zooplankton alkaline phosphatase activity in relation to water quality. Hydrobiologia , 311-316. 
14

365

366

367

368

369

370

371

372

373

374

375

376

377

378

379

380

381

382

383

384

385

386

387

388

389

390

391

392

393

394

395

396

Jansson, M., Olsson, H., \& Pettersson, K. (1988). Phosphatases; origin, characteristics and function in lakes. Hydrobiologia, 170,157-175.

Jean, N., Bogé, G., Jamet, J.L., Richard, S. , \& Jamet, D. (2003). Seasonal changes in zooplanktonic alkaline phosphatase activity in Toulon Bay (France): the role of Cypris larvae. Marine Pollution Bulletin, 46 , 346-352.

Lowry, O.H., Rosenbrough, N.J., Farr, A.L. , \& Randall, R.J.(1951). Protein measurement with folin phenol reagent. J. Biol. Chem.,193, 265-275.

McComb, R.B., Bowers, G.N., \& Posen, S. (1979). Alkaline phosphatase. Plenum Press, NY, $986 \mathrm{p}$

Nausch, M. and Nausch, G. (2004). Bacterial utilization of phosphorus pools after nitrogen and carbon amendment and its relation to alkaline phosphatase activity. Aquat. Microb. Ecol. $37,209-217$

Perona, R. \& Vallejo, C.G. (1985). Acid hydrolases during Artemia development: a role in yolk degradation. Comp. Biochem. Physiol. Part B, 81, 4, 993-1000.

Reichardt, W.J., Overbeck, J., \& Steubing, L. (1967). Free dissolved enzymes in lake waters. Nature, 216, 1345-1347

Satuito, C.G., Shimizu, K., Natoyama, K., Yamasaki, M., \& Fusetani, N. (1996) Aged-related settlement success by cyprids of the barnacle Balanus amphitrite Darwin, with special reference to consumption of cyprid storage protein. Marine Biology, 127, 125-130.

Shimizu, K., Satuito, C.G., Saikawa, W., \& Fusetani, N. (1996). Larval storage protein of the barnacle, Balanus amphytrite: biochemical and immunological similarities to vitellin. The Journal of experimental zoology, 276, 87-94.

Valiela, I. (1995) Marine Ecological Processes, Springer-Verlag, New York Inc. 


\section{Figure legends}

Fig. 1 : Structure of the zooplankton community in Toulon Bay (Mean abundances in June 2005).

Fig. 2 : Contribution, in percent of the total activity, of the high (V2) and low (V1) affinity components to the phosphatase activity of isolated larvae (N: nauplii, Z : zoe), copepodites (C) and adults (A) from Cladocera (Clad), Cyclopoids (Cycl), Calanoids (Cal), Cirripeds (Cir) and Decapods (Dec) originated from Toulon Bay

Fig. 3 : The specific activities (in nmol h $\mathrm{h}^{-1} \mathrm{\mu g}^{-1}$ protein, logarithmic scale) of the low affinity component of the phosphatase activity of isolated larvae (N: nauplii, $\mathrm{Z}$ : zoe), copepodites (C) and adults (A) from Cladocera (Clad), Cyclopoids (Cycl), Calanoids (Cal), Cirripeds (Cir) and Decapods (Dec) originated from Toulon Bay (Mean \pm Standard error).

Fig. 4 : The specific activities (in $\mathrm{nmol} \mathrm{h}^{-1} \mu \mathrm{g}^{-1}$ protein) of the high affinity component of the phosphatase activity of isolated larvae (N: nauplii, $\mathrm{Z}:$ zoe), copepodites (C) and adults (A) from Cladocera (Clad), Cyclopoids (Cycl), Calanoids (Cal), Cirripeds (Cir) and Decapods (Dec) originated from Toulon Bay (Mean \pm Standard error).

Fig. 5 : The $\mathrm{pH}$ dependence of the phosphatase activity of the Cirriped larvae (Specific activities are expressed in nmol h $\mathrm{h}^{-1} \mathrm{gg}^{-1}$ protein) (Mean \pm Standard error).

Fig. 6 : The role of cations on the of the phosphatase activity of the Cirriped larvae (Synth water : synthetic water made of $50 \mathrm{mM} \mathrm{Mg}{ }^{2+}, 20 \mathrm{mM} \mathrm{Ca}^{2+}, 500 \mathrm{mM} \mathrm{Na}^{+}$and $50 \mathrm{mM} \mathrm{K}^{+}$).

Fig. 7 : Effect of $5 \mathrm{mM} \mathrm{K}_{2} \mathrm{HPO}_{4}$ on the phosphatase activity of Cirriped larvae (Eadie Hofstee plots, and $\mathrm{Km}$ and Vmax values, $\mathrm{SW}-\mathrm{PO}_{4}$ : Sea Water without $\mathrm{PO}_{4}, \mathrm{SyW}-\mathrm{PO}_{4}$ : Synthetic Water without $\mathrm{PO}_{4}, \mathrm{SyW}+\mathrm{PO}_{4}$ : Synthetic Water with $\mathrm{PO}_{4}$, Specific activities are expressed in $\mathrm{nmol} \mathrm{h}{ }^{-1}$ $\mu \mathrm{g}^{-1}$ protein with standard errors).

Fig. 8 : Contribution, in per cent of the total activity, of external, internal and secreted activities 
to the Cirriped larvae phosphatase. 


\section{Figures}

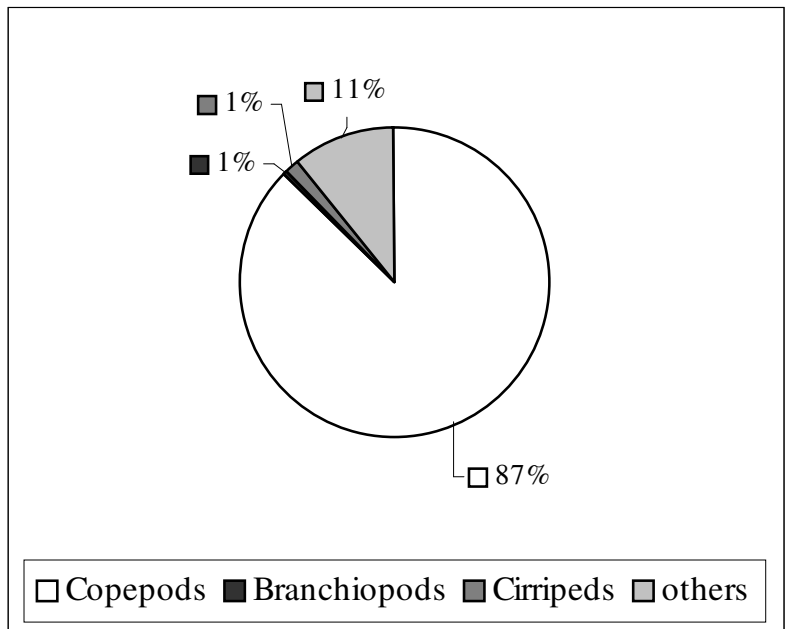

a) Crustacea

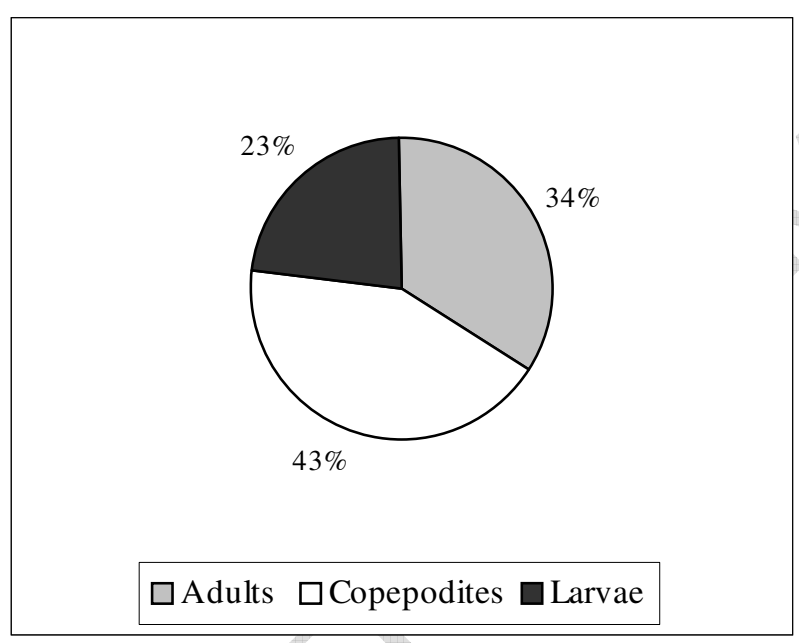

c) Development stages of zooplankton

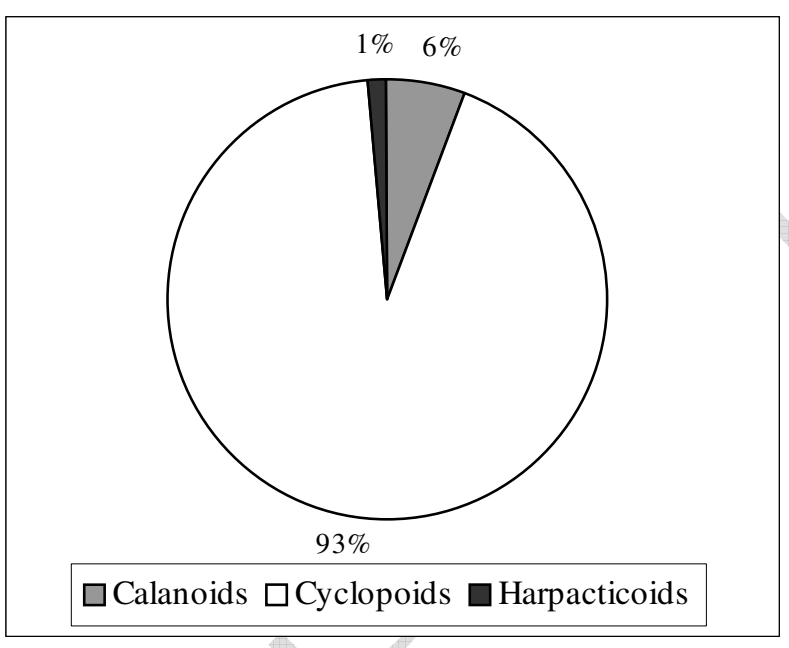

b) Copepods

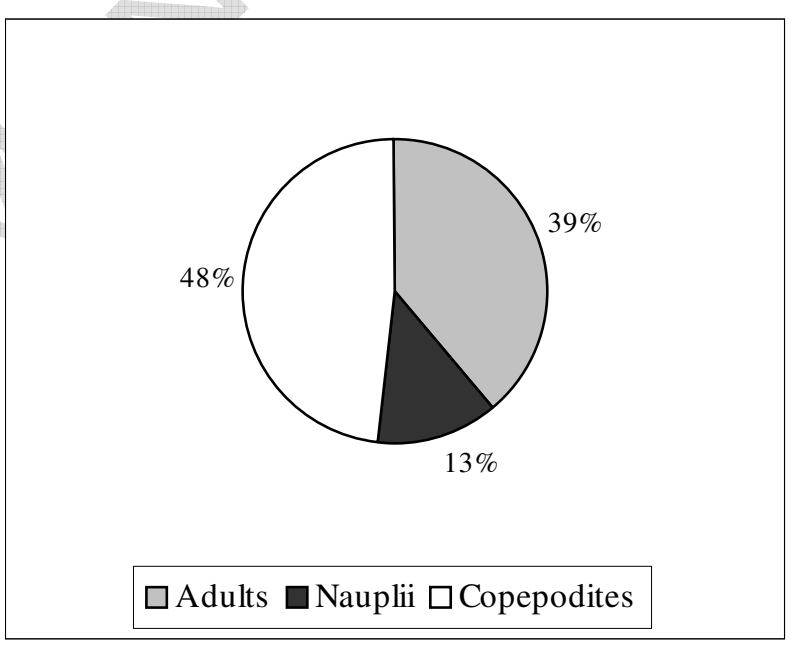

d) Development stages of Copepods

Fig. 1 


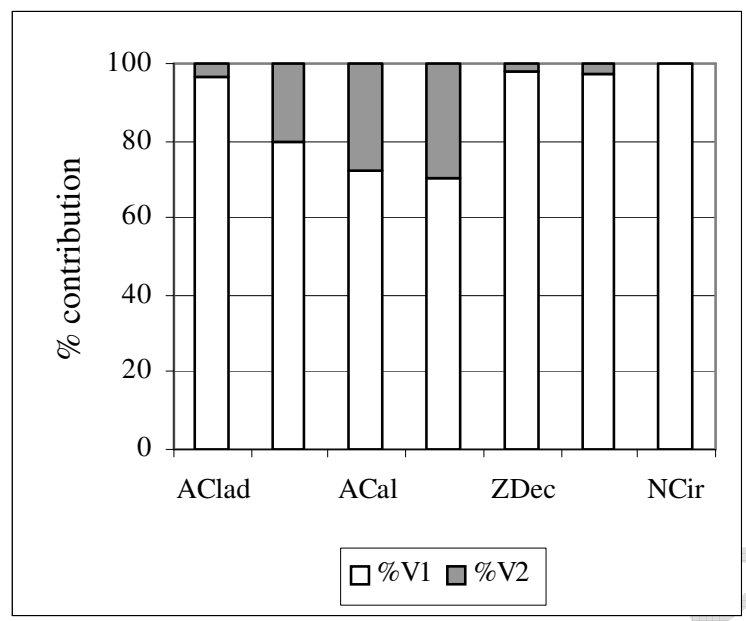

Fig. 2

Fig. 3

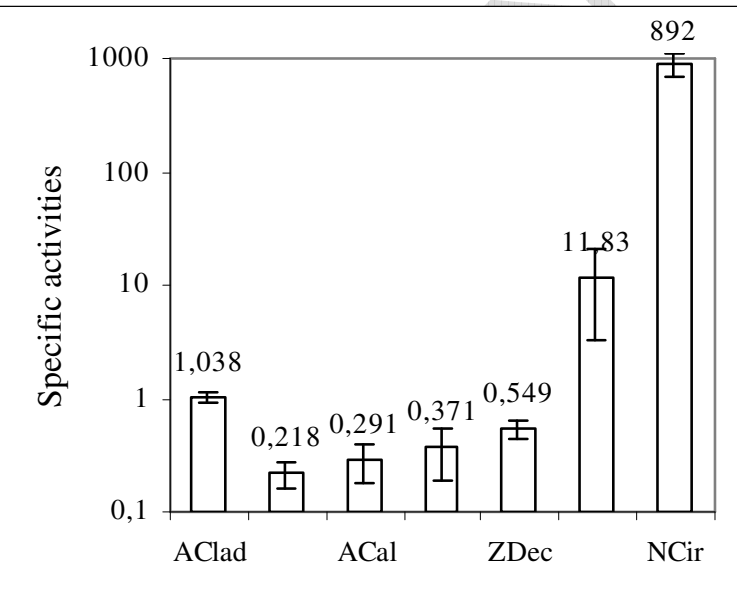




\section{ACCEPTED MANUSCRIPT}

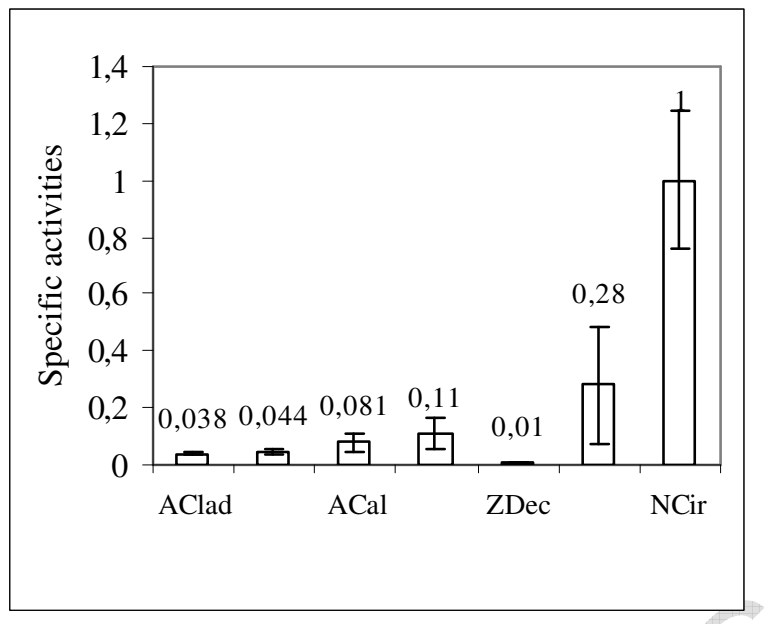

Fig. 4

Fig. 5

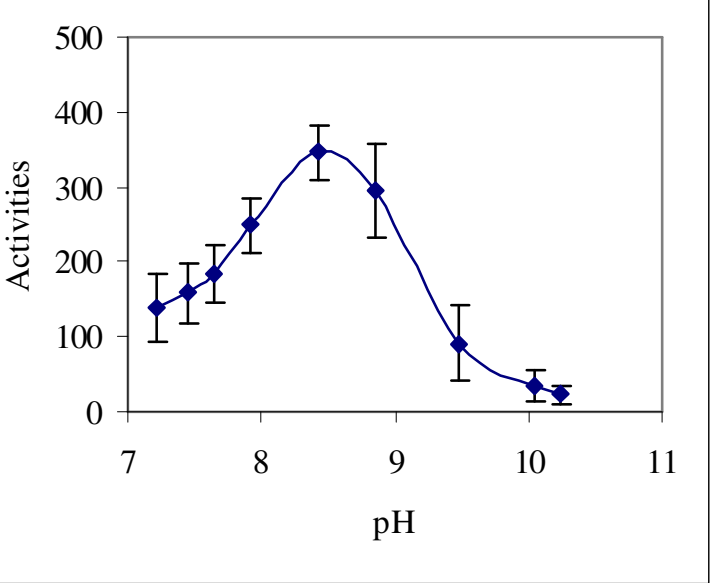




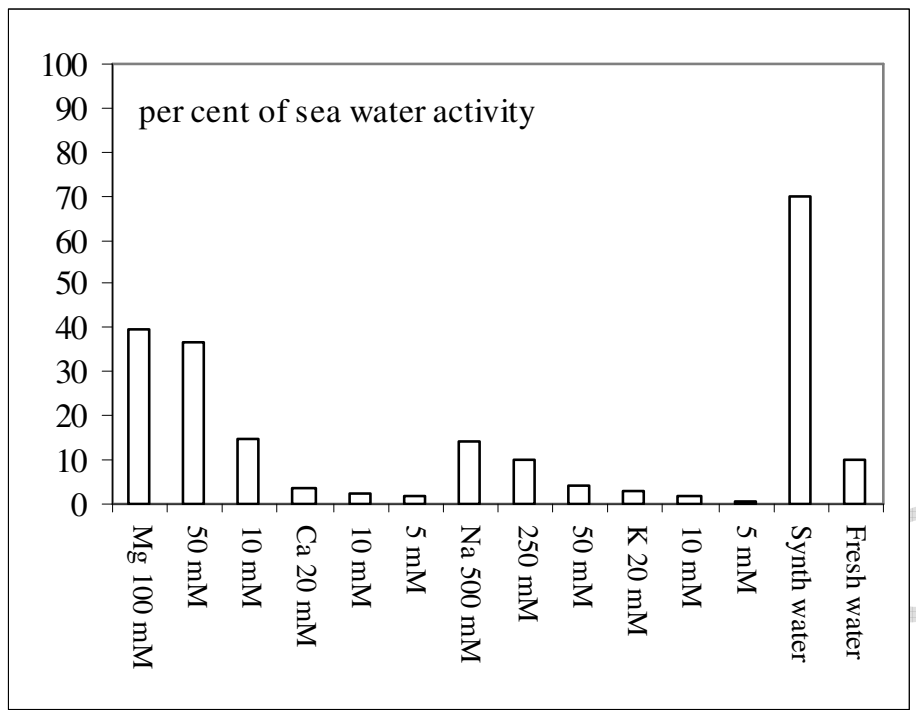

Fig. 6

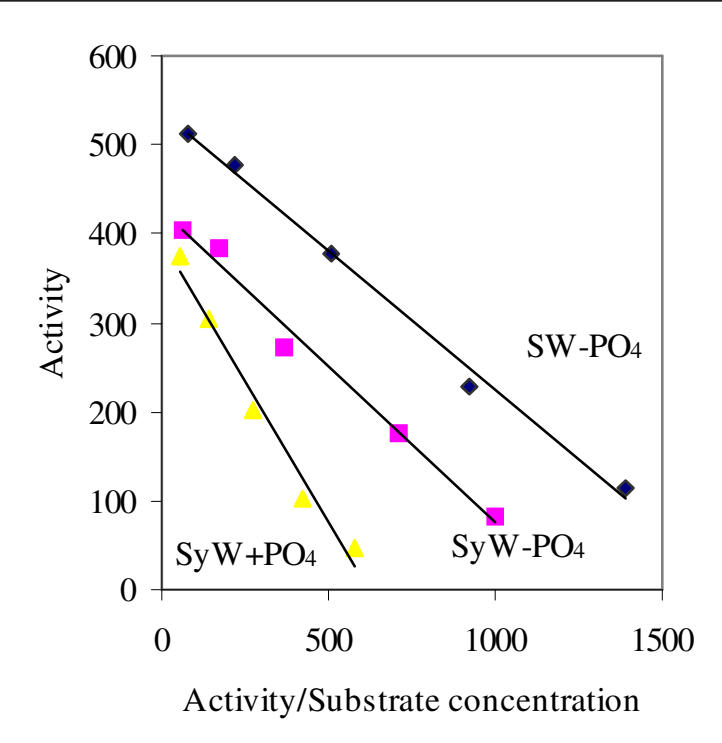

\begin{tabular}{|c|l|l|}
\hline & $\mathrm{Km}$ & $\mathrm{Vm}$ \\
\hline $\mathrm{SW}-\mathrm{PO}_{4}$ & $0,31(0,02)$ & $535(15)$ \\
\hline $\mathrm{SyW}-\mathrm{PO}_{4}$ & $0,35(0,02)$ & $425(15)$ \\
\hline $\mathrm{Sy}+\mathrm{PO}_{4}$ & $0,64(0,054)$ & $392(30)$ \\
\hline
\end{tabular}

Fig. 7 


\section{ACCEPTED MANUSCRIPT}

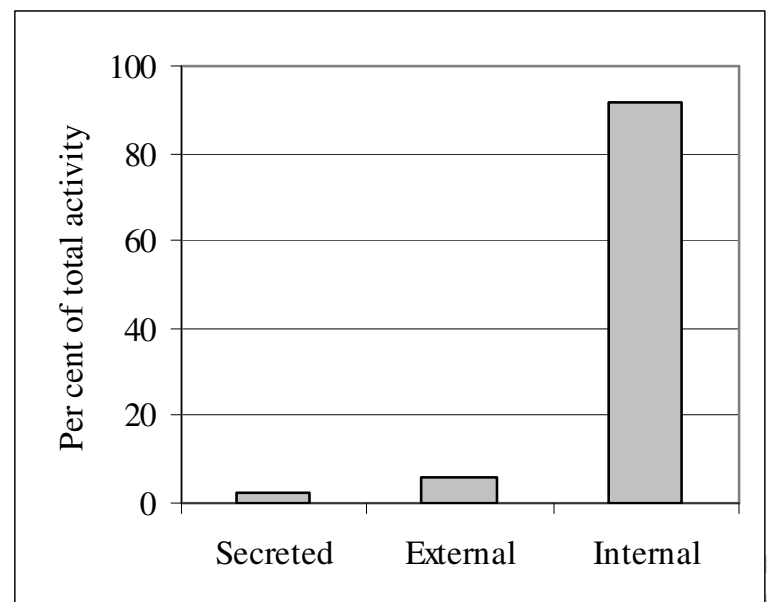

$\underline{\text { Fig. } 8}$ 